\title{
Activin and follistatin: more than \\ FSH regulators
}

\author{
A special section consisting of proceedings \\ from the Journal of Endocrinology Symposium \\ at the $189^{\text {th }}$ Meeting of the Society for \\ Endocrinology, London, $23^{\text {rd }}$ November, \\ 1998
}

\section{Foreword}

When McCullogh first described inhibin in the 1930s (McCullogh 1932) it is unlikely that he could have envisaged the turn of events that has resulted in the publications from the first Journal Symposium. In spite of a lack of enthusiasm from most of the reproductive endocrine groups around the world, some groups took up the challenge of purifying the inhibin material defined as a substance that specifically suppressed follicle-stimulating hormone (FSH) secretion by a direct action on the pituitary. A major breakthrough came when Frank de Jong and Richard Sharpe in the MRC Reproductive Biology Unit in Edinburgh, UK discovered that fluid from cow ovarian follicles contained high amounts of a substance that suppressed FSH secretion (de Jong \& Sharpe 1976). This provided the source for the eventual purification of inhibin by groups in Australia, Japan and the USA (Ling et al. 1985, Miyamoto et al. 1985, Robertson et al. 1985).

It soon emerged that inhibin was a dimer consisting of an $\alpha$ and a $\beta$ subunit, and subsequently that there were two forms of the $\beta$ subunit, $\beta A$ and $\beta B$. Thus inhibin could exist as both inhibin $A$, the $\alpha$ subunit combined with the $\beta A$ subunit, and inhibin $\mathrm{B}$, the $\alpha$ subunit combined with the $\beta \mathrm{B}$ subunit. Phil Knight in Reading first showed that a substantial amount of inhibin immunoreactivity detected in the first radioimmunoassays was free $\alpha$ subunit (Knight $e t$ al. 1989). The biological significance of the inhibin molecules only became apparent with the development of 2-site IRMAs specific for inhibin A and inhibin B by Nigel Groome at Oxford Brookes University, UK (Groome et al. 1996). It emerged that in most male mammals the testes produce only inhibin $\mathrm{B}$, whereas in most female mammals the ovaries produced both inhibin $\mathrm{A}$ and $\mathrm{B}$, the amounts varying with different stages of follicle development. It was also shown by immunoneutralisation that circulating inhibin was part of the feedback control of FSH secretion.

While these studies were concentrating on the inhibin molecule, it soon emerged that the $\beta$ subunits also had a life of their own. Fractionation of ovarian follicular fluid and analysis using an in vitro pituitary cell culture system identified a material with FSH-stimulating activity. This activity was identified as homodimers of two 'inhibin' $\beta$ subunits. This substance was named activin, and a whole new family of signalling molecules was born. Soon after this a further molecule that had weak FSH-inhibiting activity was identified, named follistatin. However, follistatin was soon shown to be a major binding protein of activin and has subsequently been shown to be a modulator of the action of activin. In 
the search for the inhibin receptor, which remains to be identified, Wylie Vale's group cloned the first of the four major activin receptors. These proved to be members of the serine/threonine protein/kinase receptor family signalling through the Smad proteins, and of the same family as, for example, the TGF $\beta$ receptors (Matthews \& Vale 1991).

With the identification of these different inhibin molecules suppressing FSH, and the activins stimulating FSH with activity modulated by follistatin, it also emerged that activins had a wide role in controlling many functions within the body as a whole, and not just FSH secretion. Many of these functions are paracrine. This symposium illustrates some of these diverse functions of the activin system and how more are emerging with time.

Thus the inhibin/activin/follistatin story illustrates just how it is often impossible to predict where good science will lead us. Who could possibly have predicted the final outcome of McCullogh's studies on the effects of a water extract of a dog testis on the castrate cells of the pituitary! I hope that this first Journal Symposium will be of interest to all endocrinologists.

A S McNeilly Editor-in-Chief

\section{References}

Groome NP, Illingworth PJ, O’Brien M, Pai R, Rodger FE, Mather JP \& McNeilly AS 1996 Measurement of dimeric inhibin B throughout the human menstrual cycle. Journal of Clinical Endocrinology and Metabolism 81 1401-1405.

de Jong FH \& Sharpe RM 1976 Evidence for inhibin-like activity in bovine follicular fluid. Nature 263 71-72.

Knight PG, Beard AJ, Wrathall JH \& Castillo RJJ 1989 Evidence that the bovine ovary secretes large amounts of monomeric inhibin alpha subunit and its isolation from bovine follicular fluid. Journal of Molecular Endocrinology 2 189-200.

Ling N, Ying S-Y, Ueno N, Esch F, Denoroy L \& Guillemin R 1985 Isolation and partial purification of a Mr32,000 protein with inhibin activity from porcine follicular fluid. Proceedings of the National Academy of Sciences of the USA 82 7217-7221.

McCullogh DR 1932 Dual endocrine activity of the testis. Science 76 19-20.

Matthews LS \& Vale WW 1991 Expression cloning of an activin receptor, a predicted transmembrane serine kinase. Cell 65 973-982.

Miyamoto K, Hasegawa Y, Fukeda M, Nomura M, Igarashi M, Kanagawa K \& Matzuo M 1985 Isolation of porcine follicular fluid inhibin at 32 KDaltons. Biochemical and Biophysical Research Communications 136 1103-1109.

Robertson DM, Foulds LM, Leversha L, Morgan FJ, Hearn MTW, Burger HG, Wettenhall REH \& de Kretser DM 1985 Isolation of inhibin from bovine inhibin follicular fluid. Biochemical and Biophysical Research Communications 126 220-226. 